\title{
THE ROLE OF SURROUNDING LANDSCAPE IN DETERMINING SPECIES RICHNESS OF MESIC GRASSLANDS IN PANNONIAN BASIN AND CARPATHIAN MOUNTAINS
}

\author{
MONIKA JANIŠOVÁ* \\ Institute of Botany, Slovak Academy of Sciences, Dúbravská cesta 9, 84523 Bratislava, \\ Slovakia \\ *Corresponding author \\ e-mail:monika.janisova@gmail.com \\ (Received 22 $2^{\text {nd }}$ Sept 2013; accepted $15^{\text {th }}$ Jan 2014)
}

\begin{abstract}
Alpha diversity of mesic grasslands of the Arrhenatheretalia order was related to the surrounding landscape structure. The following questions were addressed: i) Does structure of surrounding landscape affect local species richness? How important is the influence of surrounding landscape in comparison with influence of climatic-topographical and soil-geological variables? ii) Do the landscape effects differ in climatically distinct regions (Pannonian, Carpathian colline-submontane and Carpathian montane-subalpine)? iii) Which of the surrounding habitats contribute to species richness and which species immigrate to grasslands most frequently? Species data were extracted from Slovak vegetation plot database. Surrounding land-use (in terms of cover and diversity of various habitat types in plot neighbourhood of $4 \mathrm{~km}^{2}$ ) was derived from CORINE land cover maps and National Grassland Inventory. Both, percentage cover and diversity of different habitat types in plot neighbourhood affected local species richness. In the Pannonian Basin, mesic grasslands had the lowest species richness but the landscape factors explained the highest proportion of its variance. In the montane-subalpine Carpathian region, the effect of landscape factors was least pronounced. The surrounding landscape affected number, proportion and cover of satellite species in plots. Mesic grasslands of the Pannonian Basin hosted the largest number, proportion and cover of archaeophytes and neophytes.
\end{abstract}

Keywords: geology, land use, natural habitats, target species, satellite species

\section{Introduction}

Mesic grasslands of the Arrhenatheretalia order are widespread in the whole temperate Europe over all types of geological bedrock (Ellenberg, 1996; Dierschke and Briemle, 2002). The order includes semi-natural grasslands on fresh, regularly or occasionally improved habitats, distributed from the lowlands to the subalpine mountain zones (Dierschke, 1997; Janišová et al., 2007; Chytrý, 2012). As their habitats were created by man, along with the suitable climatic and edaphic conditions their maintenance is conditioned by traditional management both in the present and in the past (Klimek et al., 2007; Hájková et al. 2011). Due to their intermediate position along the moisture and nutrient gradients mesic habitat conditions are suitable not only for most grassland species but also for plenty of species diagnostic for other vegetation types and thus intensive immigration of species from surrounding habitats can be expected. This makes the Arrhenatheretalia communities especially suitable for a study how the surrounding landscape affects the grassland composition and species richness.

It is supposed that the habitats surrounding certain plant communities constitute sources of species which are not regular components of the given community, as their ecological optima lie in another vegetation type, but which can survive under suboptimal conditions (the so called satellite species). In such a way, all habitat types, being natural or non-natural, can constitute sources of additional plant species and thus 
contribute to increasing local grassland diversity (Hanski, 1982; Schmida and Wilson, 1985; Pärtel et al., 2001; Öster et al., 2007). The influence of the surrounding landscape, in terms of heterogeneity and habitat cover, has already been studied at different scales and on different taxa and species groups (Shmida and Wilson, 1985; Sönderström et al., 2001; Reitalu et al., 2012; Schmucki et al., 2012; Janišová et al., 2013). In this contribution, landscape structure was related to local species richness measured at very small scale within the single georeferenced phytosociological plots. A large vegetation database was used comprising several thousand of plots. The following questions were addressed: i) Does structure of surrounding landscape affect local species richness of mesic grasslands in the Carpathian-Pannonian regions of Slovakia? How important is the influence of surrounding landscape in comparison with influence of climatictopographical and soil-geological variables? ii) Do landscape effects differ in climatically distinct regions (Pannonian, Carpathian colline-submontane and Carpathian montane-subalpine)? iii) Which of the surrounding habitats contribute to species richness in mesic grasslands and which species immigrate to grasslands most frequently?

\section{Material and methods}

\section{Relevé selection}

A dataset of 1705 vegetation plots ordered to the phytosociological order Arrhenatheretalia elatioris by an electronic expert system (Janišová et al., 2007), containing 785 species of vascular plants, was used for the analyses. This dataset was extracted from the Slovak vegetation database (code EU-SK-001, Šibík, 2012), originally containing 51180 plots of all vegetation types (as of 1 January 2011). Only plots with accurate geographical location and plot size between 15 and $25 \mathrm{~m}^{2}$ were included (as there was no positive relation indicated between plot size and number of species, the whole interval of plot sizes was used to ensure enough replicates for all studied factor levels). Only plots from altitudes of up to $1600 \mathrm{~m}$ were included, which corresponds to the natural timberline in the Western Carpathian Mts. Only plots with cover of shrub and/or tree layers lower than $25 \%$ were included. To reduce the effect of oversampling in certain areas, this dataset was geographically stratified (Knollová et al., 2005). One plot of each syntaxon (determined in most cases at the level of associations by the original author) was randomly selected from a grid square of $0.5^{\prime}$ longitude and $0.3^{\prime}$ latitude (approximately $0.6 \times 0.56 \mathrm{~km}$ ) (Figure 1.). The resulting dataset included plots recorded between the years 1933 and 2010. Multiple records of species in different layers within one plot were combined so that each species appeared in each relevé only once. Bryophytes and lichens were deleted as they were not recorded in all relevés. Juvenile trees and shrubs were deleted, too.

\section{Landscape characteristics}

The effects of land use were studied in plot neighbourhoods of $4 \mathrm{~km}^{2}$ (a circle with a radius of $1.128 \mathrm{~km}$ centred at the plot). According to the CORINE land cover maps (Bossard et al., 2000), 26 habitat classes were distinguished in the neighbourhood of the studied plots. For the purpose of this study, they were combined into two main (natural and semi- natural vs. non-natural) and four subordinate habitat categories (non-forest, forest, agricultural, artificial) as summarized in Table 1. 
Table 1. Definition of habitat types used in this study based on habitat classes of CORINE land cover maps

\begin{tabular}{|c|c|c|}
\hline Habitat types & & CORINE habitat class \\
\hline \multirow{12}{*}{$\begin{array}{l}\text { Natural and semi- } \\
\text { natural habitats }\end{array}$} & \multirow[t]{9}{*}{ Non-forest habitats } & 2.3.1 Pastures \\
\hline & & $\begin{array}{l}\text { 2.4.3 Land principally occupied by agriculture with } \\
\text { significant areas of natural vegetation }\end{array}$ \\
\hline & & 3.2.1 Natural grasslands \\
\hline & & 3.2.2 Moors and heathland \\
\hline & & 3.2.4 Transitional woodland-scrub \\
\hline & & 3.3.2 Bare rocks \\
\hline & & 3.3.3 Sparsely vegetated areas \\
\hline & & 4.1.1 Inland marshes \\
\hline & & 4.1.2 Peat bogs \\
\hline & \multirow[t]{3}{*}{ Forest habitats } & 3.1.1 Broad-leaved forest \\
\hline & & 3.1.2 Coniferous forest \\
\hline & & 3.1.3 Mixed forest \\
\hline \multirow[t]{14}{*}{ Non-natural habitats } & \multirow[t]{4}{*}{ Agricultural habitats } & 2.1.1 Non-irrigated arable land \\
\hline & & 2.2.1 Vineyards \\
\hline & & 2.2.2 Fruit trees and berry plantations \\
\hline & & 2.4.2 Complex cultivation patterns \\
\hline & \multirow[t]{10}{*}{ Artificial habitats } & 1.1.1 Continuous urban fabric \\
\hline & & 1.1.2 Discontinuous urban fabric \\
\hline & & 1.2.1 Industrial or commercial units \\
\hline & & 1.2.2 Road and rail networks and associated land \\
\hline & & 1.2.4 Airports \\
\hline & & 1.3.1 Mineral extraction sites \\
\hline & & 1.3.2 Dump sites \\
\hline & & 1.3.3 Construction sites \\
\hline & & 1.4.1 Green urban areas \\
\hline & & 1.4.2 Sport and leisure facilities \\
\hline
\end{tabular}

In addition to landscape parameters calculated from CORINE land cover maps, percentage cover of ecologically valuable grasslands was estimated according to the National Grassland Inventory based on field surveys performed during 1998-2010 (Šeffer et al., 2002). For the purposes of this study, valuable grasslands were defined as biodiverse grasslands of higher nature value. They included $88 \%$ of the mapped grasslands (intensively used, fertilized and ruderal grasslands were excluded from this category directly during the field survey). The percentage cover values of six habitat categories based on the CORINE land cover maps and one category based on the National Grassland Inventory were related to local species richness of vascular plants calculated for individual vegetation plots. The Shannon diversity index of habitat diversity was calculated for each plot based on the cover of habitat classes in the plot neighbourhood of $4 \mathrm{~km}^{2}$ as $\mathrm{H}^{\prime}=-\sum \mathrm{p}_{\mathrm{i}} \ln \mathrm{p}_{\mathrm{i}}$, where $\mathrm{p}_{\mathrm{i}}$ is the proportion of each of the habitat class. The index was calculated for the diversity of (i) all habitats, (ii) natural and semi-natural habitats, (iii) natural and semi-natural non-forest habitats, and (iv) non-natural habitats. 


\section{Arrhenatheretalia elatioris}

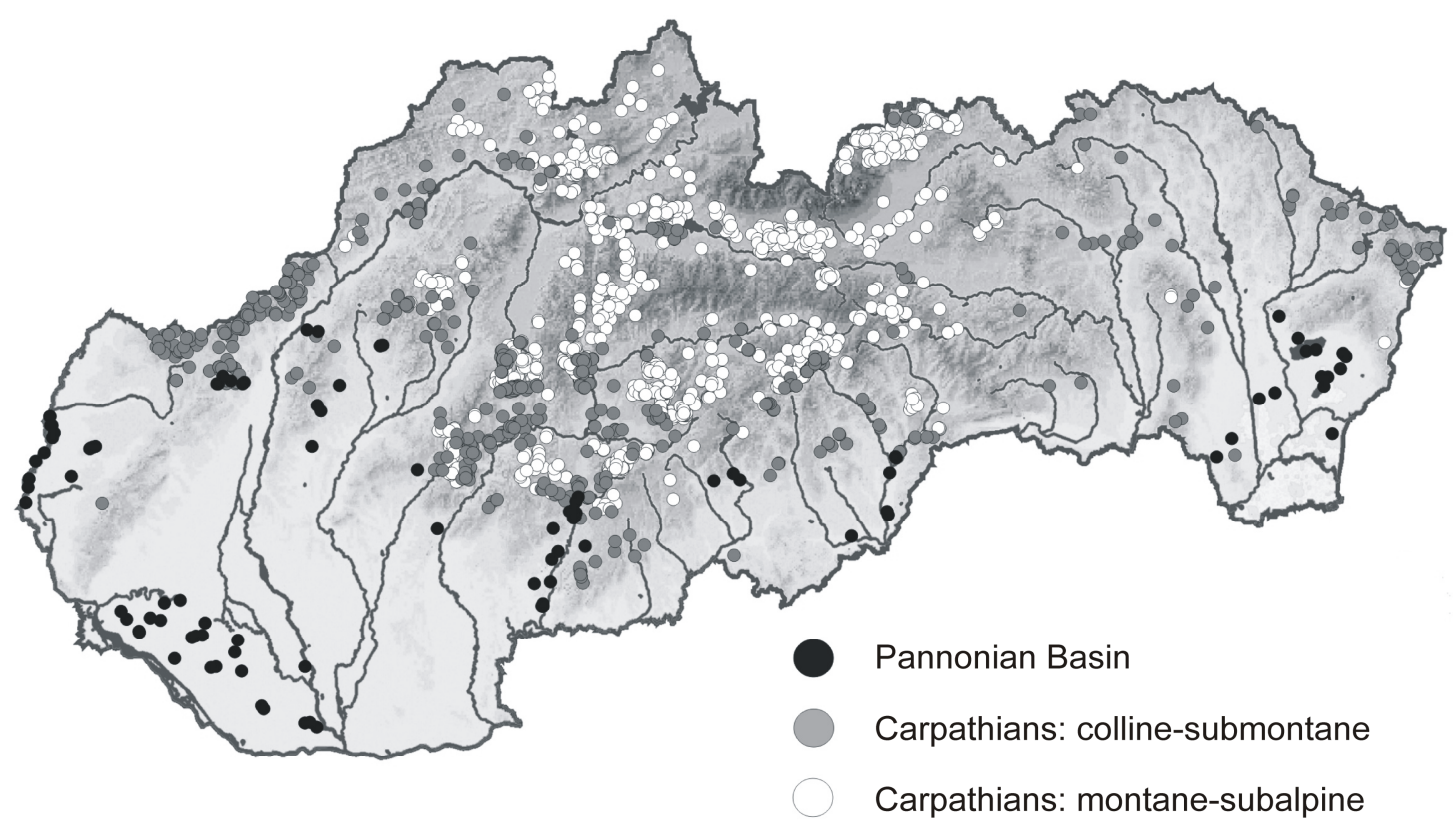

Figure 1. Distribution of the Arrhenatheretalia plots in three climatic regions of Slovakia

\section{Environmental variables}

Along with the landscape factors the following environmental factors were related to local species richness: altitude; annual precipitation and mean annual temperature (both calculated in a GIS environment using long-term measurements from period 1951-1980 and topographic data); Climatic Water Balance (index calculated as difference between precipitation and evapotranspiration used as indicator of landscape humidity during the growing season April-September; modelled in a GIS environment using the FAO Penman-Monteith equation according to Hlásny and Baláž, 2008); moisture (unweighted means of Ellenberg indicator values, according to Ellenberg et al. 2002, were used as a fine-scale surrogate for water availability at the plot location); soil reaction and soil nutrients (both expressed as unweighted means of Ellenberg indicator values). Digitalized geological map of Slovakia (Biely et al., 2002) was used to set geological bedrock of the sampled sites. For the purpose of this study, the great variety of geological substrates was converted into 6 categories: 1 - acid plutonic, volcanic or metamorphosed rocks (granites, dacites, granodiorites, ryolites, phyllites, schists and gneisses), 2 - intermediate and basic plutonic, volcanic or metamorphosed rocks (andesites, diorites, basalts, gabros, amphibolites), 3 - mesozoic sedimentary rocks (limestones and dolomites), 4 - sandstones and claystones of the flysch belt, 5 sandstones, claystones and shales of other than flysch origin, 6 - neogene and paleogene sediments (mainly claystones and sandstones).

\section{Climatic regions}

For the purpose of this paper, three climatic regions were distinguished based on the climate classification of Slovakia (based on long-term averages of temperature and 
precipitation mainly during the growing season) by Džatko at al. (1989): i) the Pannonian Basin including lowland to colline regions with warm to very warm, very dry and continental climate; ii) the colline-submontane Carpathians including regions with moderately warm to moderately cold and dry to moderately humid climate; and iii) the montane-subalpine Carpathians including regions with cold to very cold and humid climate.

\section{Categorisation of species groups}

Along with the analyses of the whole dataset (including all vascular plant species recorded in the plots) we analyzed a data sub-sets containing the following species groups: target species (typical of mesic grasslands of the Arrhenatheretalia order; 108 species), forest species (typical of forest habitats), alien species (including archaeophytes and neophytes according to Medvecká et al., 2012) and native species of non-natural habitats (typical of agricultural and urban habitats). Species typical of individual habitat types were determined on the whole Slovak Vegetation Database (geographically stratified dataset including plots of all syntaxa) by means of the phicoefficient (only species with $p h i>0.10$ were selected as typical) calculated in JUICE (Tichý 2002) with standardisation of relevé groups to equal size and using Fisher's exact test at $\mathrm{P}<0.001$ (Tichý, 2002).

\section{Data analysis}

Complex relationships between number of vascular plants and environmental variables were assessed using regression trees (Breiman et al., 1984), calculated in the STATISTICA software (StatSoft Inc., 2006). Optimal tree size was determined by tenfold cross-validation procedure with a standard error rule set to 0.1. Each decision tree was pruned (prune of variance) after the data were split, with a minimum of 100 cases per branch and a maximum of 1000 nodes per tree. The importance plots ranking the predictors on a $0-100$ scale were used to determine which variable is the most significant predictor.

Differences in number of species belonging to given species groups between the studied regions and in the region characteristics were tested by using the analysis of variance and Fisher LSD multiple comparison test in the STATISTICA program (StatSoft Inc., 2006). Series of simple linear and quadratic regressions were performed for local species richness as the dependent variable and 18 environmental factors as continuous predictors. Bonferroni correction was used setting critical values of $\alpha$ as $\alpha$ 18. The Akaike information criterion (AIC) was used to select the most appropriate model.

\section{Results}

\section{Landscape effects on local species richness of mesic grasslands in the studied regions}

Mesic grasslands in the Carpathian Mts (Fig. 1) were more species-rich (with 40 vascular plants in a plot on average) than mesic grasslands in the Pannonian Basin (with 30 vascular plants in a plot on average). This conclusion was valid also if only target Arrhenatheretalia species were considered (Fig. 2). 

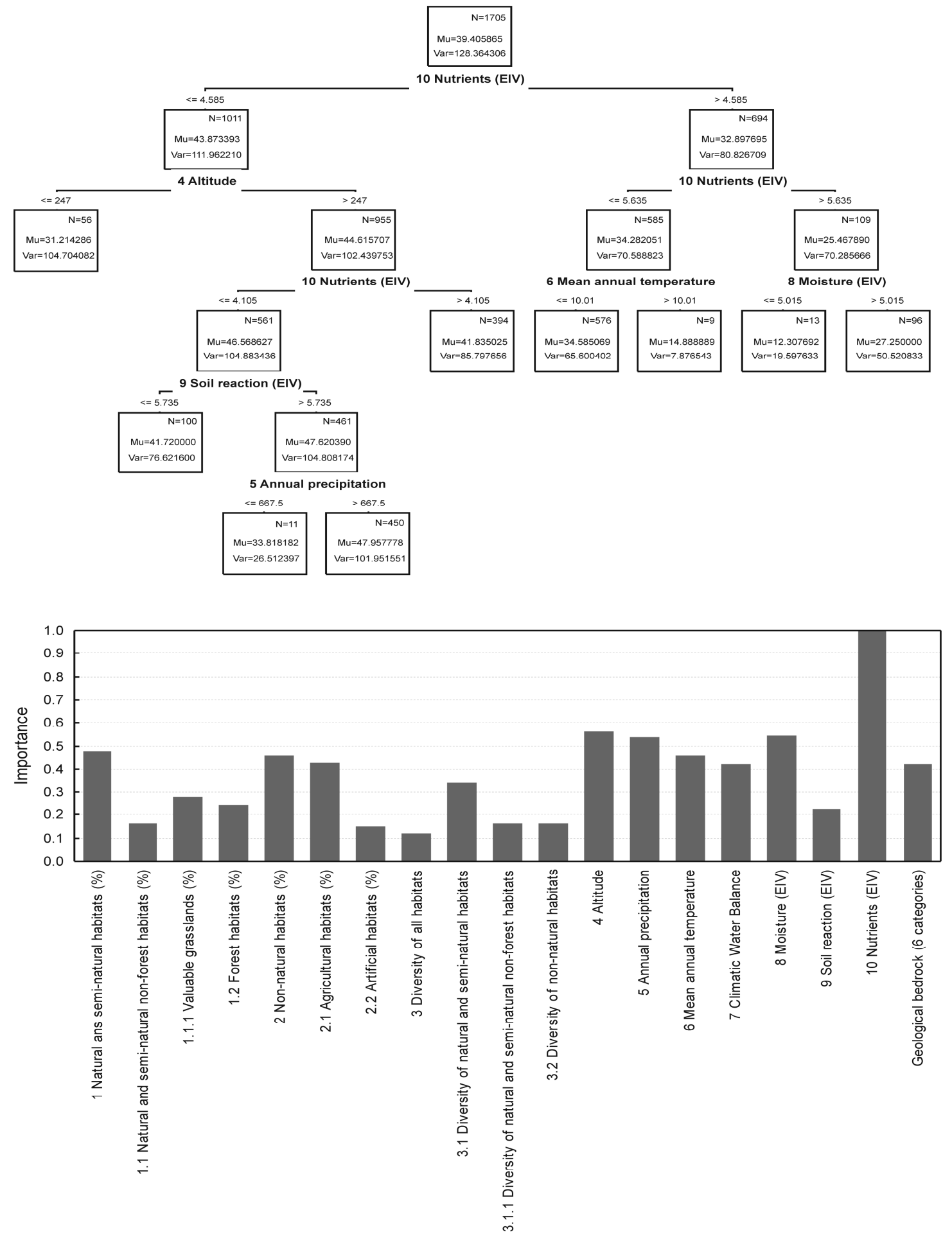

Figure 2. Average number of species in different species groups in mesic grasslands of the

Pannonian Basin (P), colline-submontane Carpathians (C1) and montane-subalpine

Carpathians (C2). $T$-target species of mesic Arrhenatheretalia meadows, $F$-forest species, $A$ - archaeophytes, $N$-neophytes, $N N$-native species of non-natural habitats, others - other species not ordered to the former groups. Differences among the regions were tested by ANOVA at alpha 0.05 and the results of multiple comparison tests are indicated by letters (values that do not differ are depicted by the same letter). 
The overall diversity of mesic grassland vegetation as reflected in the number of recorded Arrhenatheretalia phytosociological associations was also higher in the Carpathians (10 and 11 association in $\mathrm{C} 1$ and $\mathrm{C} 2$, respectively) than in the Pannonic Basin (7 associations, Table 2).

Table 2. Characteristics of the whole teritory and the three distinct climatic regions are shown. Differences among the regions were tested by ANOVA at alpha 0.05 and the results of multiple comparison tests (Fisher LSD test) are indicated by capital letters (values that do not differ are depicted by the same letter).

\begin{tabular}{|c|c|c|c|c|}
\hline Characteristics (mean \pm St. dev.) & $\begin{array}{l}\text { All climatic } \\
\text { regions }\end{array}$ & $\begin{array}{c}\text { Pannonian } \\
\text { Basin }\end{array}$ & $\begin{array}{l}\text { Carpathians } \\
\text { (colline- } \\
\text { submontane) }\end{array}$ & $\begin{array}{l}\text { Carpathians } \\
\text { (montane- } \\
\text { subalpine) }\end{array}$ \\
\hline Number of analyzed plots & 1705 & 98 & 506 & 1101 \\
\hline $\begin{array}{l}\text { Local species richness (number of all } \\
\text { vascularplants) }\end{array}$ & $39 \pm 11$ & $30 \pm 12 \mathrm{~A}$ & $40 \pm 12^{B}$ & $40 \pm 11^{B}$ \\
\hline $\begin{array}{l}1 \text { Proportion of natural and semi-natural } \\
\text { habitats } \\
1.1 \text { Proportion of natural and semi-natural } \\
\text { non-forest habitats }\end{array}$ & $\begin{array}{l}79 \pm 26 \\
37 \pm 22\end{array}$ & $\begin{array}{l}36 \pm 33^{A} \\
17 \pm 18^{A}\end{array}$ & $\begin{array}{l}71 \pm 26^{B} \\
33 \pm 20^{B}\end{array}$ & $\begin{array}{l}86 \pm 20^{C} \\
41 \pm 22^{C}\end{array}$ \\
\hline 1.1.1 Proportion of valuable grasslands & $18 \pm 17$ & $7 \pm 11^{A}$ & $13 \pm 13^{B}$ & $22 \pm 18^{C}$ \\
\hline 1.2 Proportion of forest habitats & $42 \pm 28$ & $20 \pm 26^{A}$ & $38 \pm 25^{B}$ & $45 \pm 28^{C}$ \\
\hline 2 Proportion of non-natural habitats & $21 \pm 26$ & $62 \pm 33^{C}$ & $29 \pm 26^{B}$ & $14 \pm 20^{\mathrm{A}}$ \\
\hline 2.1 Proportion of agricultural habitats & $16 \pm 23$ & $54 \pm 30^{C}$ & $22 \pm 23^{B}$ & $10 \pm 17 \mathrm{~A}$ \\
\hline 2.2 Proportion of artificial habitats & $4 \pm 8$ & $8 \pm 11^{B}$ & $6 \pm 9^{B}$ & $3 \pm 7 \mathrm{~A}$ \\
\hline $\begin{array}{l}\text { 3 Diversity of all habitats } \\
\text { 3.1 Diversity of natural and semi-natural }\end{array}$ & $1.2 \pm 0.3$ & $0.9 \pm 0.4^{\mathrm{A}}$ & $1.3 \pm 0.3^{C}$ & $1.2 \pm 0.3^{B}$ \\
\hline habitats & $0.9 \pm 0.3$ & $0.4 \pm 0.3 \mathrm{~A}$ & $0.9 \pm 0.3^{B}$ & $1.0 \pm 0.3^{C}$ \\
\hline non-forest habitats & $0.5 \pm 0.2$ & $0.3 \pm 0.2^{\mathrm{A}}$ & $0.5 \pm 0.2^{B}$ & $0.5 \pm 0.2^{c}$ \\
\hline 3.3 Diversity of non-natural habitats & $0.3 \pm 0.2$ & $0.4 \pm 0.2^{c}$ & $0.4 \pm 0.3^{B}$ & $0.2 \pm 0.2^{\mathrm{A}}$ \\
\hline 4 Altitude ( $\mathrm{m}$ a.s.l.) & $620 \pm 237$ & $177 \pm 72 \mathrm{~A}$ & $416 \pm 98^{B}$ & $754 \pm 166^{C}$ \\
\hline 5 Annual precipitation (mm) & $857 \pm 137$ & $624 \pm 55^{A}$ & $793 \pm 81^{B}$ & $907 \pm 129 \mathrm{C}$ \\
\hline 6 Mean annual temperature $\left({ }^{\circ} \mathrm{C}\right)$ & $5.9 \pm 1.4$ & $9.1 \pm 0.9^{C}$ & $7.0 \pm 0.9^{B}$ & $5.2 \pm 0.9 \mathrm{~A}$ \\
\hline 7 Climatic Water Balance (index) & $-17 \pm 124$ & $-242 \pm 57^{A}$ & $-93 \pm 80^{B}$ & $39 \pm 101 \mathrm{C}$ \\
\hline $\begin{array}{l}8 \text { Moisture (unweighted means of Ellenberg } \\
\text { indicatorvalues) }\end{array}$ & $4.8 \pm 0.5$ & $4.7 \pm 0.6^{\mathrm{A}}$ & $4.6 \pm 0.5^{\mathrm{A}}$ & $4.8 \pm 0.5^{\mathrm{B}}$ \\
\hline $\begin{array}{l}9 \text { Soil reaction(unweighted means of } \\
\text { Ellenberg indicator values) }\end{array}$ & $6.3 \pm 0.6$ & $6.7 \pm 0.5^{B}$ & $6.6 \pm 0.5^{B}$ & $6.2 \pm 0.6^{\mathrm{A}}$ \\
\hline $\begin{array}{l}10 \text { Soil nutrients (unweighted means of } \\
\text { Ellenberg indicator values) }\end{array}$ & $4.5 \pm 0.7$ & $4.5 \pm 0.9^{\mathrm{A}}$ & $4.5 \pm 0.7^{\mathrm{A}}$ & $4.4 \pm 0.7^{\mathrm{A}}$ \\
\hline $\begin{array}{l}\text { Arrhenatherion elatioris (number of } \\
\text { associations) }\end{array}$ & 5 & 4 & 5 & 5 \\
\hline $\begin{array}{l}\text { Cynosurion cristati (number of associations) } \\
\text { Polygono bistorti-Irisetion flavescentis }\end{array}$ & 3 & 3 & 3 & 2 \\
\hline (number of associations) & 4 & 0 & 2 & 4 \\
\hline $\begin{array}{l}\text { Total number of the Arrhenatheretalia } \\
\text { associatios }\end{array}$ & 12 & 7 & 10 & 11 \\
\hline
\end{tabular}

The studied regions differed in many characteristics of the surrounding landscape. In the Pannonian Basin the average proportion of non-natural habitats was 2-3 times higher and the proportion of natural and semi-natural habitats was 2 times lower than in the 
Carpathians. Similarly, diversity of natural and semi-natural habitats increased towards high altitudes and harsh montane climate. Diversity of non-natural habitats was lowest in the montane-subalpine Carpathians while the Carpathian colline-submontane regions and the Pannonian Basin did not differ in this characteristic (Table 2).

Irrespectively from the region, local species richness of the studied grasslands increased with increasing diversity or percentage cover of different natural and seminatural habitats in the plot neighbourhood. Conversely, local species richness decreased with higher proportion or diversity of non-natural habitats in the surroundings. According to simple regression models (Table 3), proportion of all natural and seminatural habitats explained the highest percentage variance in local species richness in all studied regions. Among the landscape factors, it was the best predictor of high local species richness in mesic grasslands, while proportion of all non-natural habitats was the best predictor of low local species richness. Diversity of natural and semi-natural habitats including the diversity of non-forest habitats was important mainly in the Pannonian Basin. Percentage of variance explained by single regression models was much higher for the Pannonian Basin than for the Carpathian regions in all studied landscape factors.

\section{Landscape effects in comparison with effects of other environmental factors}

In the whole dataset without regard to climatic regions, soil nutrients and moisture (both expressed by Ellenberg indicator values) explained the highest percentage variance in single regression models for local species richness (Table 3). The landscape factors and the other environmental factors studied explained lower, but similar percentage variance. Similar results were obtained by the regression tree analysis (Fig. 3 ). The optimal regression tree for local species richness had nine terminal nodes. The first split was based on nutrients (EIV), with lower species richness associated with nutrient-rich grasslands (694 of 1705 plots). The other group of nutrient-poor grasslands was further split by altitude, which separated species-poorer sites at lowest altitudes from other sites. Plots at higher altitudes were further divided into a species-poorer group in nitrogen-richer sites, and the remaining group of plots was further split by soil reaction (EIV). The more species-rich group in more basiphilous habitats was finally divided according to annual precipitation where a small group of 11 plots with lower precipitation was species poorer than the rest of plots. For nutrient-rich group, the next division was also based on nutrients (EIV), with higher richness at the nutrient-poorer sites, this group of plots further split according to the mean annual temperature. The most nutrient-rich plots were further divided by moisture and the drier group reached the absolutely lowest species richness in the dataset.

The effect of geological bedrock as the only categorical variable was studied for the whole dataset (Fig. 4). Number of target species was the highest in mesic grasslands on sandstones, claystones, intermediate (mainly andesites) and basic rocks (mainly basalts) and the lowest on neogene and paleogene sediments. Calcareous and acid substrates had intermediate richness of target species. There were no differences in number of satellite species (including forest species and all species of non-natural habitats) among plots on different geological bedrock. The highest number of other species (including mainly generalist species and species of semi-natural non-forest habitats other than mesic grasslands) was found on mesosoic sedimentary rocks and sandstones, claystones and shales of other than flysh origin. 
Table 3. Summary of simple regression models for local species richness as dependent variable and environmental factors as predictors Linear and quadratic relationships were compared and the model with lower AIC is presented by arrows $\uparrow$ or $\downarrow$ for linear relationships, $\cap$ for hump-back and U for U-shape quadratic relationships. Percentage variance of dependent variable explained by the model is shown in the parentheses. Significant relationships were indicated after using Bonferroni correction. Regression models for moisture, soil reaction and soil nutrients based on Ellenberg indicator values were corrected using the modified permutation test (Zelený \& Schaffers 2012). ${ }^{*} P<0.05$, ** $P<0.01$ and $* * * P<0.001$, n.s. - non significant.

\begin{tabular}{|c|c|c|c|c|}
\hline Environmental factors & $\begin{array}{l}\text { All climatic } \\
\text { regions }\end{array}$ & $\begin{array}{c}\text { Pannonian } \\
\text { Basin }\end{array}$ & $\begin{array}{l}\text { Carpathians } \\
\text { (colline- } \\
\text { submontane) }\end{array}$ & $\begin{array}{l}\text { Carpathians } \\
\text { (montane- } \\
\text { subalpine) }\end{array}$ \\
\hline \multicolumn{5}{|l|}{ Landscape factors } \\
\hline 1 Natural and semi-natural habitats (\%) & $\cap * * *(7.9)$ & $\cap * * *(42.9)$ & $\mathrm{U}^{* * *}(6.6)$ & $\cap * *(1.7)$ \\
\hline $\begin{array}{l}1.1 \text { Natural and semi-naturalnon-forest } \\
\text { habitats }(\%)\end{array}$ & $\cap * * *(1.2)$ & $\cap * * *(27.5)$ & $\uparrow^{* *}(2.9)$ & n.s. \\
\hline 1.1.1 Valuable grasslands (\%) & $\cap * * *(3.1)$ & $\cap * * *(19.8)$ & $\uparrow * *(3.5)$ & n.s. \\
\hline 1.2 Forest habitats (\%) & $\cap * * *(3.0)$ & $\cap^{* * *}(29.7)$ & n.s. & $\uparrow^{* *}(1.2)$ \\
\hline 2 Non-natural habitats (\%) & $\cap * * *(3.0)$ & $\cap * * *(37.9)$ & $\mathrm{U}^{* * *}(6.5)$ & $\cap * *(1.6)$ \\
\hline 2.1 Agricultural habitats (\%) & $\cap * * *(6.6)$ & $\cap * * *(22.1)$ & $\downarrow * * *(5.5)$ & $\cap *(1.3)$ \\
\hline 2.2 Artificial habitats (\%) & $\mathrm{U}^{* * *}(1.7)$ & $\mathrm{U}^{* * *}(20.3)$ & $\mathrm{U}^{*}(2.7)$ & n.s. \\
\hline 3 Diversity of all habitats & $\cap * * *(1.3)$ & $\uparrow * *(15.0)$ & n.s. & n.s. \\
\hline $\begin{array}{l}\text { 3.1 Diversity of natural and semi-natural } \\
\text { habitats }\end{array}$ & $\cap * * *(6.0)$ & $\uparrow * * *(37.8)$ & n.s. & $\cap * *(1.5)$ \\
\hline $\begin{array}{l}\text { 3.1.1 Diversity of natural and semi- } \\
\text { naturalnon-forest habitats }\end{array}$ & $\cap * * *(1.3)$ & $\cap * * *(27.3)$ & n.s. & n.s. \\
\hline 3.2 Diversity of non-natural habitats & $\downarrow * * *(2.1)$ & n.s. & $\mathrm{U}^{* * *}(5.2)$ & n.s. \\
\hline \multicolumn{5}{|l|}{ Climatic-topographical factors } \\
\hline 4 Altitude (m a.s.l.) & $\cap * * *(5.8)$ & $\cap * * *(39.8)$ & $\cap * *(3.2)$ & $\cap * *(1.5)$ \\
\hline 5 Annual precipitation (mm) & $\cap * * *(5.9)$ & $\cap * * *(23.8)$ & $\uparrow * * *(4.4)$ & $\cap *(1.1)$ \\
\hline $6 \mathrm{Mean}$ annual temperature $\left({ }^{\circ} \mathrm{C}\right)$ & $\cap * * *(5.6)$ & $\cap * * *(37.1)$ & n.s. & n.s. \\
\hline 7 Climatic Water Balance (index) & $\cap * * *(4.6)$ & $\cap * * *(28.9)$ & n.s. & $\cap *(1.2)$ \\
\hline \multicolumn{5}{|l|}{ Soil-geological factors } \\
\hline $\begin{array}{l}8 \text { Moisture (unweighted means of } \\
\text { Ellenberg indicator values) }\end{array}$ & $\mathrm{U}^{* * *}(10.4)$ & n.s. & $\mathrm{U}^{* * *}(12.5)$ & $\mathrm{U}^{* * *}(1.5)$ \\
\hline $\begin{array}{l}9 \text { Soil reaction(unweighted means of } \\
\text { Ellenberg indicator values) }\end{array}$ & $\cap *(0.6)$ & n.s. & n.s. & $\uparrow * * *(2.2)$ \\
\hline $\begin{array}{l}10 \text { Soil nutrients (unweighted means of } \\
\text { Ellenberg indicator values) }\end{array}$ & $\cap * * *(28.8)$ & $\cap * *(14.8)$ & $\cap * * *(29.9)$ & $\downarrow^{* * *}(31.4)$ \\
\hline
\end{tabular}

\section{Satellite species provided by surrounding habitats}

Out of 785 species in the whole dataset, 108 were identified as target species of the Arrhenatheretalia grasslands, the rest of species were either the generalist species 
occurring in various types of habitats or the satellite species, colonizing the studied grasslands from the neighbouring communities (satellite species). Among the satellite species, 78 species were typical of forest habitats, 49 were archaeophytes, 15 neophytes and 38 species were native species typical of non-natural habitats. In comparison with the Carpathians, mesic grasslands in the Pannonian Basin contained less target species in the target species pool and individual plots and less forest species in the forest species pool and individual plots (Table 4). Contrastingly, they contained more archaeophytes, neophytes and native species of non-natural habitats in individual plots, while number of these species in the regional species pools did not differ from the Carpathian regions.

Table 4. The size of regional species pools for individual species groups and average number of species belonging to particular species groups in plots (in parentheses)

\begin{tabular}{|l|c|c|c|}
\hline & Pannonian Basin & $\begin{array}{c}\text { Carpathians } \\
\text { colline-submontane }\end{array}$ & $\begin{array}{c}\text { Carpathians } \\
\text { montane-subalpine }\end{array}$ \\
\hline Target species & $94(18)$ & $107(30)$ & $108(30)$ \\
\hline Forest species & $16(0.4)$ & $51(0.9)$ & $71(1.0)$ \\
\hline Archaeophytes & $35(1.6)$ & $35(0.8)$ & $32(0.4)$ \\
\hline Neophytes & $10(0.3)$ & $10(0.2)$ & $10(0.1)$ \\
\hline $\begin{array}{l}\text { Native species of } \\
\text { non-natural habitats }\end{array}$ & $26(1.2)$ & $27(0.9)$ & $29(0.8)$ \\
\hline
\end{tabular}

Satellite species recorded in mesic grassland plots are listed in Appendix 1.

\section{Discussion}

As shown in previous studies (Steiner \& Köhler, 2003; Schmucki et al., 2012; Janišová et al., 2013), grassland species richness is affected by the surrounding landscape and mesic grasslands belong to the most affected communities due to their central position on the moisture and nutrient gradients and suitable habitat conditions for most of the generalist species. The results of this study emphasize the role of landuse history and landscape structure in shaping the composition and diversity of grassland ecosystems. Lower local species richness in the Pannonian Basin may not only be the result of lowland more continental climate in this region which is less suitable for maintenance of mesophilous grassland communities, but also the result of long-lasting intensive human influence. Due to the transformation of grasslands to agricultural fields, reduction in size and diversity of natural and semi-natural habitats and resulting course and uniform landscape structure, the remaining grassland patches resemble islands isolated in the intensive agricultural landscape. Grassland species pool in this region has been gradually reduced due to insufficient connectivity and size of grassland complexes. This may be the reason why average mesic grassland plot in the Pannonian Basin hosts by one quarter less vascular plant species than a comparable plot in the Carpathians. Although the diversity of non-natural habitats is much higher in the Pannonian Basin than in the Carpathians, the enrichment by archaeophytes and native 
species of non-natural habitats is not sufficient to increase significantly the overall local species richness of these meadows.

Among the abiotic habitat conditions, nutrient status of habitat seems to play the most important role for determination of local species richness in the studied grasslands. Negative influence of excess nutrients (mainly phosphorus and potassium) on vascular plant species richness was found in many studies dealing with various types of grassland vegetation (e.g. Janssens et al., 1998; Critchley et al., 2002; Hejcman et al., 2007; Merunková \& Chytrý, 2012) and it is attributed mainly to change of dominant species and an increase of sward height. Moisture availability was another important predictor of local species richness in the studied grasslands. Moisture gradient is considered to be the main determinant of compositional change in most European grassland communities (e.g. Merunková \& Chytrý, 2012; Moeslund et al., 2013). Our study confirmed the importance of moisture for grassland diversity and suggests that both, topographically controlled soil moisture expressed by average Ellenberg indicator values and precipitation as a broad-scale surrogate for water availability are good predictors of species richness in mesic grasslands (Table 3, Fig. 3).

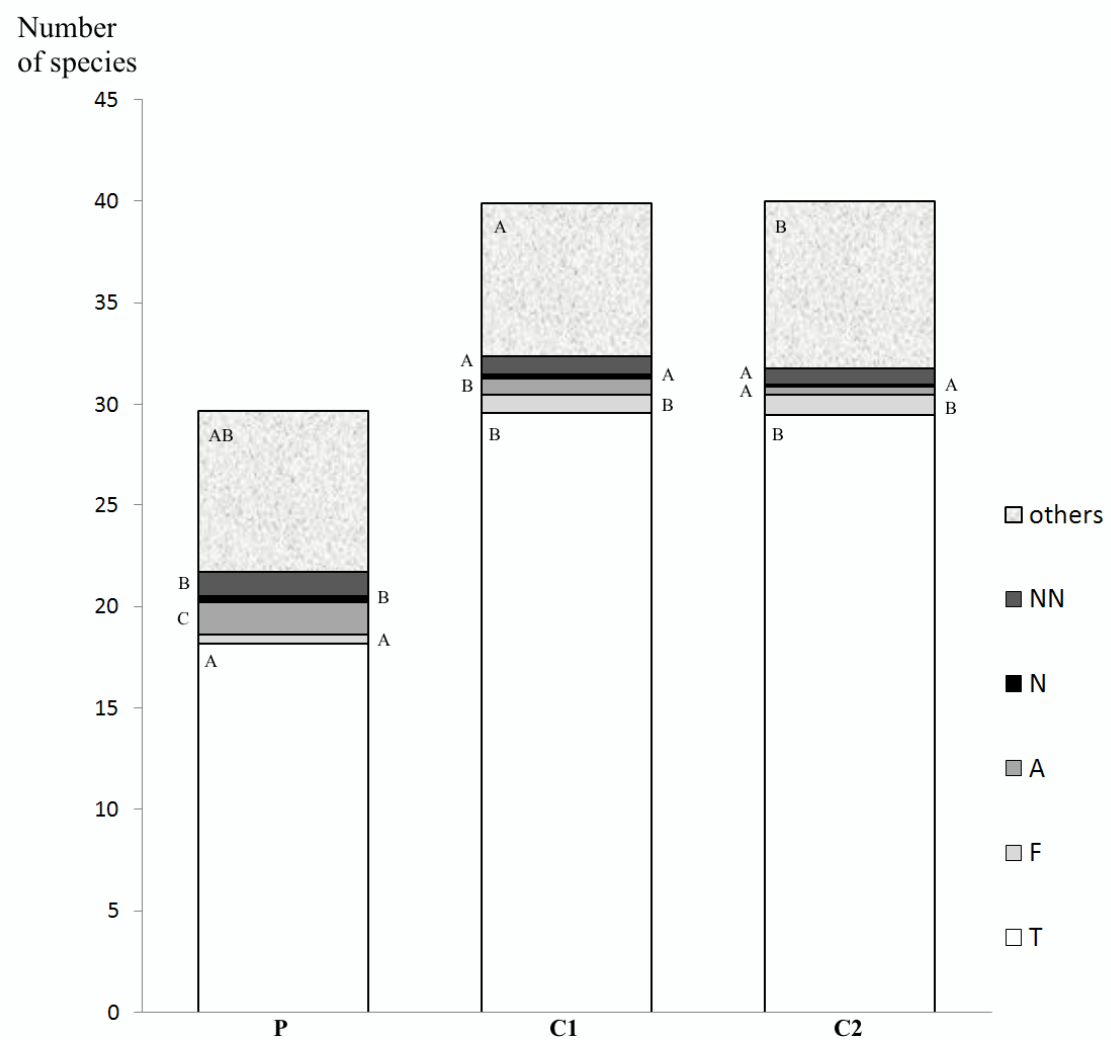

Figure 3. Regression tree for local species richness $\left(15-25 \mathrm{~m}^{2}\right)$ and relative importance of environmental factors for prediction of local species richness. Mean number of vascular plant species (Mu), variance (Var) and number of plots ( $N$ ) belonging to a node are given at each node. EIV: plot means of unweighted Ellenberg indicator values.

Most of the studied climatic-topographical and soil-geological factors had stronger influence on local species richness than the studied landscape factors if all grassland plots were taken into consideration (Fig. 2, Table 3). However, in the Pannonian Basin, 
landscape factors had comparable importance and one of the landscape factors (proportion of natural and semi-natural habitats) explained the largest proportion of variance in local species richness. This suggests special importance of landscape context in the regions strongly modified by human activities. The obtained results emphasize the importance of careful landscape planning for maintaining diverse grassland communities and avoiding spread of invasive alien species.

Mesic grasslands differed in their species composition and diversity also as a result of different geological bedrock. Sandstones, claystones, andesites and basalts seem to provide optimal habitat condition for development of species-rich mesic grassland communities as they support the highest number of target grassland species (Fig. 4a).

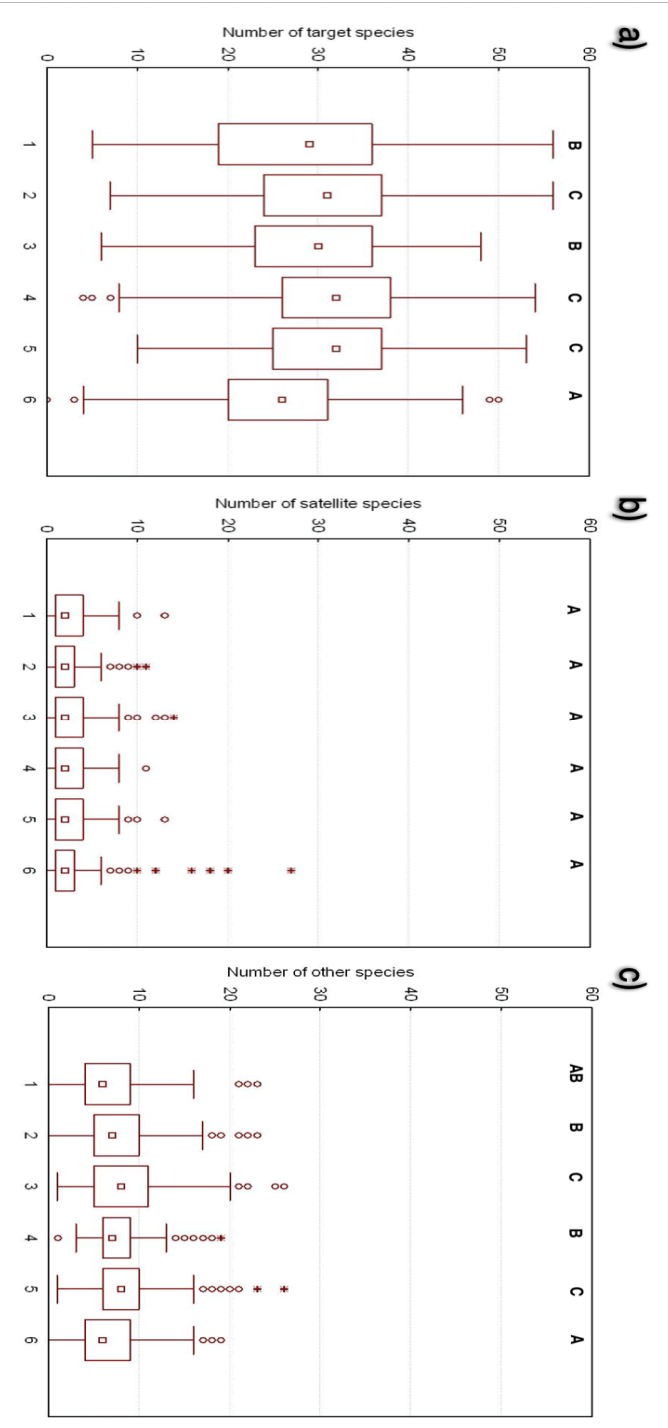

Figure 4. Effect of geological bedrock on species richness of a) target, b) satellite and c) other species in mesic grasslands of Slovakia. Geological bedrock: 1 - acid plutonic, volcanic or metamorphosed rocks, 2 - intermediate and basic plutonic, volcanic or metamorphosed rocks, 3

- mesozoic sedimentary rocks, 4 - sandstones and claystones of the flysch belt, 5 - sandstones, claystones and shales of other than flysch origin, 6 - neogene and paleogene sediments.

Differences among regions were tested by ANOVA at alpha 0.05 and the results of multiple comparison tests are indicated by letters (values that do not differ are depicted by the same letter). 
As sandstones and claystones also can support high number of generalist species and species of other natural and semi-natural non-forest habitats (Fig. 4c), the most speciesrich mesic grasslands can be found especially on this kind of geological bedrock. High number of "other" species indicated in mesic grasslands on calcareous bedrock (Fig. 4c) supports the idea of large species pool of calcareous species in Europe as suggested by Ewald (2003). On the other hand, occurrence of satellite species (both from natural and non-natural habitats) seems not to be dependent on the bedrock type and is rather influenced by the structure of the surrounding landscape.

Acknowledgements. I would like to thank Rastislav Lasák for provision of data from the National Grassland Inventory and calculation of habitat cover in plot neighbourhood, Tomáš Hlásny for provision of climatic and topographical data for vegetation plots, Pavol Král' for help with regression analyses, and all vegetation scientists (mainly Helena Ružičková) who contributed to the Slovak Vegetation Database. Financial support: VEGA 2/0099/13.

\section{REFERENCES}

[1] Biely, A., Bezák, V., Elečko, M. (2002): Geologická stavba. - In: Atlas krajiny Slovenskej republiky. SAŽP, Banská Bystrica.

[2] Bossard, M., Feranec, J., Ot'ahel, J. (2000): CORINE Land Cover Technical Guide Addendum 2000. - European Environmental Agency, Copenhagen.

[3] Breiman, L., Friedman, J. H., Olshen R. A., Stone C. J. (1984): Classification and regression trees. - Wadsworth International Group, Belmont.

[4] Chytrý, M. (2012): Vegetation of the Czech Republic. - Preslia 84: 427-504.

[5] Critchley, C.N.R., Chambers, B.J., Fowbert, J.A., Sanderson, R.A., Bhogal, A., Rose S.C. (2002): Association between lowland grassland plant communities and soil properties. Biological Conservation 105: 199-215.

[6] Dierschke, H. (1997): Synopsis der Pflanzengesellschaften Deutschlands. Heft 3. Molinio-Arrhenatheretea (E 1). Kulturgrasland und verwandte Vegetationstypen. Teil 1: Arrhenatheretalia. Wiesen und Weiden frischer Standorte. - Floristisch-soziologische Arbeitsgemeinschaft \& Reinhold-Tüxen-Gesellschaft, Göttingen.

[7] Dierschke, H. \& Briemle, G. (2002): Kulturgrasland: Wiesen, Weiden und verwandte Staudenfluren. - Ulmer, Stuttgart.

[8] Džatko, M., Mašát, K., Cambel, B. (1989): Agroklimatické regióny SR. - VCPÚ-ÚPVR, Bratislava.

[9] Ellenberg, H. (1996): Vegetation Mitteleuropas mit den Alpen in ökologischer, dynamischer und historischer Sicht. Ed. 5. - Verlag Eugen Ulmer, Stuttgart.

[10] Ellenberg, H., Weber, H. E., Düll, R., Wirth, W., Werner, W., Paulissen, D. (1992): Zeigerwerte von Pflanzen in Mitteleuropa. Goltze, Göttingen.

[11] Ewald, J. (2003): The calcareous riddle: Why are there so many calciphilous species in the Central European flora? - Folia Geobotanica 38: 357-366.

[12] Hájková, P., Roleček, J., Hájek, M., Horsák, M., Fajmon, K., Polák, M, Jamrichová E. (2011): Prehistoric origin of the extremely species-rich semi-dry grasslands in the Bílé Karpaty Mts (Czech Republic and Slovakia). - Preslia 83: 185-204.

[13] Hanski, I. (1982): Dynamics of regional distribution: the core and satellite species hypothesis. - Oikos 38: 210-221.

[14] Hejcman, M., Klaudisová, M., Štursa, J., Pavlů, V, Schellberg, J., Hejcmanová, P., Hakl, J., Rauch, O., Vacek S. (2007): Revisiting a 37 years abandoned fertilizer experiment on Nardus grassland in the Czech Republic. - Agriculture Ecosystems \& Environment 118: 231-236. 
[15] Hlásny, T., Baláž, P. (2008): The climatic water balance of Slovakia based on the FAO Penman-Monteith potential evapotranspiration. - Geografický Časopis 60: 15-30.

[16] Janišová, M., Hájková, P., Hegedüšová, K., Hrivnák, R., Kliment, J., Michálková, D., Ružičková, H., Řezníčková, M., Tichý, L., Škodová, I., Uhliarová, E., Ujházy, K., Zaliberová, M. (2007): Travinnobylinná vegetácia Slovenska - elektronický expertný systém na identifikáciu syntaxónov. - Botanický ústav SAV, Bratislava.

[17] Janišová, M., Michalcová, D., Baccaro, G., Ghisla, A. (2014): Landscape effects on diversity of semi-natural grasslands. - Agriculture Ecosystems \& Environment 184 [In print].

[18] Janssens, F., Peeters, A., Tallowin, J.R.B., Bakker, J.P., Bekker, R.M., Fillat, F., Oomes, M.J.M. (1998): Relationship between soil chemical factors and grassland diversity. Plant Soil 202: 69-78.

[19] Klimek, S., Kemmermann, A. R., Hofmann, M., Isselstein J. (2007): Plant species richness and composition in managed grasslands: The relative importance of field management and environmental factors. - Biological Conservation 134: 559-570.

[20] Marhold, K., Hindák F. (1998): Zoznam nižších a vyšších rastlín Slovenska. VEDA, Bratislava.

[21] Medvecká, J., Kliment, J., Májeková, J., Halada, L., Zaliberová, M., Gojdičová, E., Feráková, V., Jarolímek, I. (2012): Inventory of the alien flora of Slovakia. - Preslia 84: 257-309.

[22] Merunková, K., Chytrý, M. (2012): Environmental control of species richness and composition in upland grasslands of the southern Czech Republic. - Plant Ecology 213: 591-602.

[23] Moeslund, J.E., Arge, L., Bøcher, P.K., Dalgaard, T., Ejrnæs, R., Odgaard, M.V., Svenning, J.-C. (2013): Topographically controlled soil moisture drives plant diversity patterns within grasslands. - Biodiversity and Conservation 22: 2151-2156.

[24] Öster, M., Cousins, S.A.O., Eriksson, O., 2007. Size and heterogeneity rather than landscape context determine plant species richness in semi-natural grasslands. - Journal of Vegetation Science 18: 859-868.

[25] Pärtel, M., Moora, M., Zobel M. (2001): Variation in species richness within and between calcareous (alvar) grassland stands: the role of core and satellite species. - Plant Ecology 157: 205-213.

[26] Reitalu, T., Purschke, O., Johansson, L.J., Hall, K., Sykes, M.T., Prentice, H.C., 2012. Responses of grassland species richness to local and landscape factors depend on spatial scale and habitat specialization. - Journal of Vegetation Science 23: 41-51.

[27] Schmucki, R., Reimark, J., Lindborg, R., Cousins, S.A.O. (2012): Landscape context and management regime structure plant diversity in grassland communities. - Journal of Ecology 100: 1164-1173.

[28] Söderström, B., Svensson, B., Vessby, K., Glimskär, A. (2001): Plants, insects and birds in semi-natural pastures in relation to local habitat and landscape factors. Biodiversity and Conservation 10: 1839-1863.

[29] StatSoft Inc. (2006): Electronic Statistics Textbook. Statsoft, Tulsa http://www. statsoft.com/text-book/stahme.html (31.1.2013)

[30] Shmida, A., Wilson, M.V. (1985): Biological determinants of species diversity. - Journal of Biogeography 12: 1-20.

[31] Steiner, N.C., Köhler, W. (2003): Effects of landscape patterns on species richness-a modelling approach. - Agriculture Ecosystems \& Environment 98: 353-361.

[32] Šeffer, J., Lasák, R., Galvánek, D., Stanová, V. (2002): Grasslands of Slovakia. Final report on National Grassland Inventory 1988-2002. - DAPHNE - Institute of Applied Ecology, Bratislava.

[33] Šibík, J. (2012): Slovak vegetation database. - Biodiversity \& Ecology 4: 429.

[34] Tichý, L. (2002): JUICE, software for vegetation classification. - Journal of Vegetation Sciemce 13: 451-453. 
[35] Zelený, D., Schaffers, A.P. (2012): Too good to be true: pitfalls of using mean Ellenberg indicator values in vegetation analyses. - Journal of Vegetation Science 23: 419-431.

\section{Appendix}

Appendix 1. List of satellite species recorded in mesic grassland plots (for species present only in certain region, the abbreviation $P, C 1$ or $C 2$ is given in parentheses)

Forest species: Ajuga reptans, Anemone nemorosa (C1, C2), Anemone ranunculoides (C2), Asarum europaeum (C1, C2), Astragalus glycyphyllos, Brachypodium sylvaticum (C1, C2), Calamagrostis arundinacea (C2), Campanula persicifolia (C1, C2), Campanula rapunculoides $(\mathrm{C} 1, \mathrm{C} 2)$, Campanula trachelium $(\mathrm{C} 1, \mathrm{C} 2)$, Carex alba $(\mathrm{C} 1$, $\mathrm{C} 2)$, Carex digitata (C1, C2), Carex montana (C1, C2), Carex muricata agg., Carex pilosa (C1), Carex sylvatica, Cirsium erisithales (C1, C2), Clinopodium vulgare, Convallaria majalis (C2), Daphne mezereum (C2), Dentaria bulbifera (C1, C2), Digitalis grandiflora (C1, C2), Dryopteris filix-mas (C1, C2), Epilobium montanum (C2), Festuca altissima (C1), Festuca heterophylla (C1), Fragaria moschata (C1, C2), Fragaria vesca, Galium odoratum (C2), Galium schultesii (P, C2), Genista tinctoria $(\mathrm{C} 1, \mathrm{C} 2)$, Gentiana asclepiadea $(\mathrm{C} 1, \mathrm{C} 2)$, Geranium robertianum $(\mathrm{C} 1)$, Geum urbanum, Hacquetia epipactis (C1), Hieracium lachenalii (C2), Hieracium murorum (P, C2), Hieracium racemosum (P), Hieracium sabaudum, Hypericum montanum (C2), Isopyrum thalictroides (C1), Lathyrus niger (C2), Lathyrus vernus $(\mathrm{C} 1, \mathrm{C} 2)$, Lilium martagon (C2), Luzula luzulina (C2), Luzula luzuloides (C1, C2), Luzula sylvatica (C2), Maianthemum bifolium ( $1, C 2)$, Melampyrum sylvaticum (C2), Melica nutans $(\mathrm{C} 1, \mathrm{C} 2)$, Mercurialis perennis $(\mathrm{C} 1, \mathrm{C} 2)$, Oxalis acetosella $(\mathrm{C} 1, \mathrm{C} 2)$, Paris quadrifolia (C1), Petasites albus (C2), Platanthera bifolia (C1, C2), Poa nemoralis, Polygonatum multiflorum (C1, C2), Polygonatum odoratum (C1, C2), Polygonatum verticillatum (C2), Pulmonaria mollis (C1, C2), Pulmonaria officinalis agg., Pyrethrum corymbosum (C1, C2), Ranunculus lanuginosus (C2), Rubus idaeus (C2), Rubus saxatilis (C2), Sanicula europaea (C2), Scrophularia nodosa (C1, C2), Senecio ovatus (C2), Soldanella hungarica (C2), Solidago virgaurea (C1, C2), Stachys sylvatica (C2), Stellaria holostea (C1, C2), Symphytum tuberosum, Tithymalus amygdaloides (C2), Vaccinium myrtillus (C2), Vicia cassubica (C2), Viola reichenbachiana, Viola riviniana $(\mathrm{C} 1, \mathrm{C} 2)$.

Archaeophytes: Adonis aestivalis (P), Anchusa officinalis (P, C1), Anthemis arvensis, Apera spica-venti (C1), Arctium lappa (C1, C2), Arctium tomentosum (C1, C2), Ballota nigra (C1), Berteroa incana (P, C2), Bromus arvensis (C1), Bromus tectorum (P), Capsella bursa-pastoris, Cardaria draba (P, C1), Carduus acanthoides, Chelidonium majus (P), Cichorium intybus, Convolvulus arvensis, Cynodon dactylon (P), Fallopia convolvulus (P, C1), Geranium dissectum (C1, C2), Geranium pusillum, Lactuca serriola, Lamium amplexicaule (P), Lamium purpureum (P), Lathyrus tuberosus, Lepidium campestre (C1, C2), Marrubium vulgare $(\mathrm{P})$, Melampyrum arvense $(\mathrm{C} 1, \mathrm{C} 2)$, Melilotus albus (C1, C2), Melilotus officinalis, Myosotis arvensis, Raphanus 
raphanistrum (C1, C2), Reseda lutea (P), Scleranthus annuus, Senecio vulgaris (C1), Silene latifolia $\mathrm{ssp}$. alba $(\mathrm{P})$, Sinapis arvensis $(\mathrm{C} 1, \mathrm{C} 2)$, Sonchus arvensis $(\mathrm{C} 2)$, Thlaspi arvense ( $\mathrm{P}, \mathrm{C} 2)$, Tithymalus platyphyllos (P), Tripleurospermum perforatum, Valerianella locusta, Verbena officinalis (P, C2), Veronica agrestis (C1, C2), Veronica arvensis, Vicia angustifolia, Vicia hirsuta, Vicia sativa, Viola arvensis, Viola odorata.

Neophytes: Conyza canadensis (P, C2), Erigeron annuus, Juncus tenuis (C1, C2), Malva moschata (P, C1), Matricaria discoidea, Medicago sativa, Medicago x varia (C1), Oenothera biennis agg. (P), Onobrychis viciifolia agg., Oxalis dillenii (P), Rumex thyrsiflorus $(\mathrm{P})$, Solidago gigantea $(\mathrm{P})$, Trifolium hybridum, Veronica peregrina (C2), Veronica persica $(\mathrm{C} 1)$.

Abbreviations: EIV: Ellenberg indicator values, P: Pannonian Basin, C1: collinesubmontane Carpathians, C2: montane-subalpine Carpathians

Plant nomenclature: Marhold and Hindák (1998) 